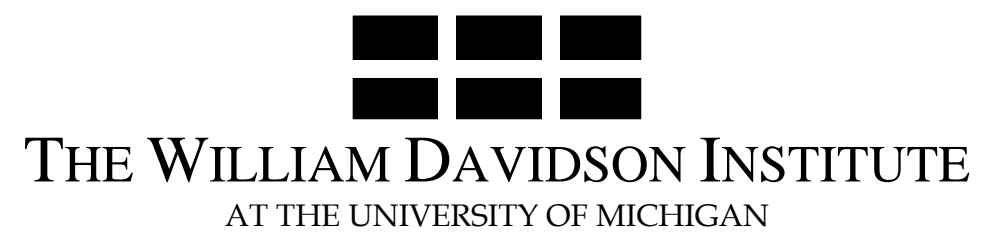

AT THE UNIVERSITY OF MICHIGAN

\title{
Oil prices and stock markets: what drives what in the Gulf Corporation Council countries?
}

\author{
By: Christophe Rault, Mohamed El Hedi Arouri
}

William Davidson Institute Working Paper Number 960

June 2009 


\title{
Oil prices and stock markets: what drives what in the Gulf Corporation Council countries?
}

\author{
Mohamed El Hedi AROURI \\ LEO, University of Orléans and EDHEC ${ }^{1}$ \\ Christophe RAULT \\ LEO, University of Orléans, CESifo, IZA, and William Davidson Institute ${ }^{2}$
}

\begin{abstract}
In the empirical literature, only few studies have focused on the relationship between oil prices and stock markets in net oil-importing countries. In net oil-exporting countries this relationship has not been widely researched. This paper implements the panel-data approach of Kónya (2006), which is based on SUR systems and Wald tests with country-specific bootstrap critical values to study the sensitivity of stock markets to oil prices in GCC (Gulf Corporation Council) countries. Using two different (weekly and monthly) datasets covering respectively the periods from 7 June 2005 to 21 October 2008, and from January 1996 to December 2007, we show strong statistical evidence that the causal relationship is consistently bi-directional for Saudi Arabia. Stock market price changes in the other GCC member countries do not Granger cause oil price changes, whereas oil price shocks Granger cause stock price changes. Therefore, investors in GCC stock markets should look at the changes in oil prices, whereas investors in oil markets should look at changes in the Saudi stock market.
\end{abstract}

Key words: GCC stock markets, oil prices.

JEL classifications: G12, F3, Q43.

\footnotetext{
${ }^{1}$ Université d’Orléans, LEO, CNRS, UMR 6221, Rue de Blois-B.P.6739, 45067 Orléans Cedex 2, France and EDHEC. Email: mohamed.arouri@univ-orleans.fr.

${ }^{2}$ Université d’Orléans, LEO, CNRS, UMR 6221, Rue de Blois-B.P.6739, 45067 Orléans Cedex 2, France; CESifo and IZA, Germany; and William Davidson Institute at the University of Michigan, Ann Arbor, Michigan, USA; email: chrault@hotmail.com. Web-site: http://chrault3.free.fr/ (corresponding author).
} 


\section{Non-Technical Summary}

This article contributes to the literature by investigating whether or not oil price changes have significantly affected stock market returns in the last years. In fact, during these years price volatility for both crude oil and related products has been great. Unlike most previous papers, which focus on the U.S., European and major Asian stock markets, our paper analyses the impact of oil price fluctuations on Gulf Corporation Council (GCC) markets. These markets are interesting for several reasons. First, GCC countries have attracted increasing attention in recent years. In the wake of high oil prices since 2003, they have developed into hubs of global economic growth. They have also become important international investors and trade partners, and play a crucial role in world energy markets. Indeed, GCC countries are major exporters of oil in global energy markets, so their stock markets may be susceptible to changes in oil prices. However, the transmission mechanisms of oil price shocks to stock returns in GCC markets should be different from those in net oil-importing countries. Second, the GCC markets differ from those of developed and from those of major emerging countries in that they are largely segmented from the international markets and are overly sensitive to regional political events. Finally, GCC markets are very promising areas for international portfolio diversification. Studying the influence of oil price shocks on GCC stock market returns can help investors make necessary investment decisions and for policy-makers regulate stock markets more effectively.

In the literature, relatively little work has focused on the sensitivity of the stock markets in oil-importing countries to oil price changes. The case of oil-exporting countries is not well investigated. This paper studied the relationship between oil prices and stock markets in GCC countries. GCC members are major net oil-exporters and important OPEC members and their 
economies are excessively dependent on oil prices. Thus, their actions as decision makers in OPEC may take into account their impact on GCC stock markets and economic activities.

Using the panel-data approach of Kónya (2006), which is based on SUR systems and Wald tests with country-specific bootstrap critical values, and two different (weekly and monthly) datasets covering respectively the periods from 7 June 2005 to 21October 2008, and from January 1996 to December 2007, we show strong statistical evidence that the causal relationship is consistently bi-directional for Saudi Arabia. In the other GCC countries, stock market price changes do not Granger cause oil price changes, whereas oil price shocks Granger cause stock price changes. Therefore, investors and policy makers in the GCC stock markets should keep an eye on changes in oil prices because these changes significantly affect stock returns. On the other hand, investors in world oil markets should look at changes in the Saudi stock market because theses changes significantly affect oil prices. 


\section{Introduction}

This article contributes to the literature by investigating whether or not oil price changes have significantly affected stock market returns in the last years. In fact, during these years price volatility for both crude oil and related products has been great. Unlike most previous papers, which focus on the U.S., European and major Asian stock markets, our paper analyses the impact of oil price fluctuations on Gulf Corporation Council (GCC) markets. These markets are interesting for several reasons. First, GCC countries have attracted increasing attention in recent years. In the wake of high oil prices since 2003, they have developed into hubs of global economic growth. They have also become important international investors and trade partners, and play a crucial role in world energy markets. Indeed, GCC countries are major exporters of oil in global energy markets, so their stock markets may be susceptible to changes in oil prices. However, the transmission mechanisms of oil price shocks to stock returns in GCC markets should be different from those in net oil-importing countries. Second, the GCC markets differ from those of developed and from those of major emerging countries in that they are largely segmented from the international markets and are overly sensitive to regional political events. Finally, GCC markets are very promising areas for international portfolio diversification. Studying the influence of oil price shocks on GCC stock market returns can help investors make necessary investment decisions and for policy-makers regulate stock markets more effectively.

A large body of recent work examines the links between oil prices and macroeconomic variables. This work has underscored the significant effects of oil price fluctuations on economic activity in mature and in emerging markets [Cunado and Perez de Garcia (2005), Balaz and Londarev (2006), Gronwald (2008), Cologni and Manera (2008), Kilian (2008), and Lardic and Mignon (2006, 2008)]. Despite studies showing that oil price shocks have significant effects on the economy, relatively fewer works have looked into the relationship 
between oil prices and stock markets. Furthermore, most of this research has focused on developed oil importers; very little has looked at emerging markets or exporters. The pioneering paper by Jones and Kaul (1996) tests the reaction of international stock markets (Canada, UK, Japan, and US) to oil price shocks on the basis of the standard cash flow dividend valuation model. They found that for the US and Canada this reaction can be accounted for entirely by the impact of the oil shocks on cash-flows. The results for Japan and the UK were inconclusive. Using an unrestricted vector autoregressive (VAR), Huang et al. (1996) show a significant link between some American oil company stock returns and oil price changes. However, they find no evidence of a relationship between oil prices and market indices such as the S\&P500. In contrast, Sadorsky (1999) applies an unrestricted VAR with GARCH effects to American monthly data and shows a significant relationship between oil price changes and aggregate stock returns.

Some works have more recently focused on major European, Asian and Latin American emerging markets. In general, these studies show significant short- and long-term relationships between oil price changes and emerging stock market returns. Using a VAR model, Papapetrou (2001) shows a significant relationship between oil price changes and stock markets in Greece. Basher and Sadorsky (2006) use an international multifactor model and reach the same conclusion for other emerging stock markets. However, less attention has been paid to smaller emerging markets, especially in the GCC countries where share dealing is a relatively recent phenomenon. Using VAR models and cointegration tests, Hammoudeh and Eleisa (2004) show that there is a bidirectional relationship between Saudi stock returns and oil price changes. The findings also suggest that the other GCC markets are not directly linked to oil prices and are less dependent on oil exports and are more influenced by domestic factors. Bashar (2006) uses VAR analysis to study the effect of oil price changes on GCC 
stock markets and shows that only the Saudi and Omani markets have the power to predict increases in the price of oil. More recently, Hammoudeh and Choi (2006) have examined the long-term relationship among the GCC stock markets in the presence of the US oil market, the S\&P500 index and the US Treasury bill rate. They find that the T-bill rate has a direct impact on these markets, while oil and the S\&P500 have indirect effects.

As we can see, the findings of the little available work on GCC countries are contradictory. These findings are puzzling because the GCC countries are heavy oil exporters and have similar economic structures. Furthermore, the GCC economies are oil dependent and are thus sensitive to oil price changes. But previous results are based on country analysis and use time series data from relatively short periods. Our paper differs from previous studies by applying a recent bootstrap panel causality test to examine the relationship between oil and stock markets in GCC countries.

The advantages of panel-data methods in the macro-panel setting include the use of data for which the spans of individual time series data are insufficient for the study of many hypotheses. Other advantages include better properties of the testing procedures when compared to more standard time series methods, and that many of the issues studied, including the relationship between oil prices and stock markets, naturally lend themselves to these methods.

In addition, in the specific approach we use in this paper, we allow for cross-country correlation, with no need to pre-test for unit roots. This question is crucial and responds to the complex nature of the interactions and dependencies that generally exist over time and across the individual units in the panel. For instance, observations of firms, industries, regions and 
countries tend to be cross-correlated as well as serially dependent. As pointed out by Breitung and Pesaran (2005), the cross-section dependence can arise for a variety of reasons, including spatial spill-over effects, common unobserved shocks, social interactions, or a combination of these factors. For our paper, cross-dependence can mirror cultural similarities, common financial, economic and social policies in GCC countries, high dependency on the revenues generated from oil exports, herding, contagion, and volatility transmission.

Our econometric investigation is based on two different complementary (weekly and monthly) datasets, respectively from 7 June 2005 to 21 October 2008, and from January 1996 to December 2007. There are two main reasons for this. Firstly, we think that weekly data may adequately capture the interaction of oil and stock prices in the region better than any other data frequency. However, our weekly data set, which deals with all the six GCC countries, only includes less than four years of data, which can be considered as too short to test for causality. Indeed, as emphasizes by Shiller and Perron (1985) it is not the frequency (number of observations) rather the span (number of years) of the data that is more important to test for random walk hypothesis of economic variables or causal relationships. Secondly, our monthly database which covers twelve years of data only includes four GCC countries out of six and doesn't permit to draw any conclusion about Qatar and United Arab Emirates which are absent from the database. Consequently, given data availability, using simultaneously the two different datasets can be seen as test of robustness of our econometric results.

The rest of the paper is organized as follows. Section 2 briefly presents the GCC markets and discusses the role of oil. Section 3 presents the data and discusses the results of the empirical analysis, while section 4 provides summary conclusions and policy implications. 


\section{GCC economies, stock markets and the role of oil}

The GCC was established in 1981 and it includes six countries, namely, Bahrain, Oman, Kuwait, Qatar, Saudi Arabia and the United Arab Emirates (UAE). GCC countries share several common patterns. Together, they produce about $20 \%$ of all world oil, control $36 \%$ of world oil exports and possess $47 \%$ of proven reserves. Oil exports largely determine earnings, government budget revenues and expenditures and aggregate demand. Table 1 shows some key financial indicators for the GCC economies. The contributions of oil to GDP range from 22\% in Bahrain to $44 \%$ in Saudi Arabia. Moreover, Table 1 indicates that for the three largest GCC economies - Saudi Arabia, UAE, and Kuwait-the liquidity of the stock market is positively associated with the importance of oil in these economies.

The rationale for using oil price movements as a factor affecting stock valuations is that, in theory, the value of stock equals the discounted sum of expected future cash flows. These cash flows are affected by macroeconomic events that can be influenced by oil shocks. Indeed, oil exports affect the main economic variables in GCC countries: earnings, government budget revenues and expenditures and aggregate demand. So oil price increases should positively affect corporate output and earnings, and then stock returns in these countries. However, GCC countries are also importers of manufactured goods from developed and emerging countries. Therefore, oil price fluctuations can indirectly impact GCC markets through their influence on the prices of imported products and in this case increases in the price of oil are often indicative of inflationary pressure in the GCC economies, pressure that could indicate the future of interest rates and investment of all types. In short, oil price fluctuations should affect corporate output and earnings, domestic prices and stock market share prices in GCC countries. However, unlike the link, expected to be negative, between oil prices and stock markets in net-oil importing countries, the link between oil price shocks and 
stock market returns in GCC countries is ambiguous and the total impact of oil price shocks on stock returns depends on which of the positive and negative effects offset the other.

Table 1- GCC economies, stock markets and oil in 2007

\begin{tabular}{lcccc}
\hline Market & $\begin{array}{c}\text { Number of } \\
\text { companies* }\end{array}$ & $\begin{array}{c}\text { Market } \\
\text { Capitalization } \\
\text { (\$ billion) }\end{array}$ & $\begin{array}{c}\text { Market Capitalization } \\
\text { (\% GDP) }\end{array}$ & $\begin{array}{c}\text { Oil } \\
\text { (\% GDP)+ }\end{array}$ \\
\hline Bahrain & 50 & 21.22 & 158 & 22 \\
Kuwait & 175 & 193.50 & 190 & 35 \\
Oman & 119 & 22.70 & 40 & 41 \\
Qatar & 40 & 95.50 & 222 & 42 \\
UAE & 99 & 240.80 & 177 & 32 \\
S. Arabia & 81 & 522.70 & 202 & 44 \\
Sources: Arab Monetary Fund and Emerging Markets Database. * Numbers in 2006.
\end{tabular}

Table 1 also shows that Saudi Arabia leads the region in terms of market capitalization. The Saudi stock market represents more than $40 \%$ of all GCC markets. However, in comparison to each country’s GDP, Qatar is the leader. Stock market capitalization exceeded GDP for all counties except Oman. Kuwait, followed by Oman, has the largest number of listed companies. Overall, GCC stock markets are limited by several structural and regulatory weaknesses: relatively small numbers of listed firms, large institutional holdings, low sector diversification, and several other deficiencies. In recent years, however, legal, regulatory, and supervisory changes have increased market transparency. The liquidity of GCC markets has improved and operations were opened to foreign investors. In March 2006 Saudi authorities lifted the restriction that limited foreign residents to dealing only in mutual funds and the other markets have progressively followed suit. ${ }^{3}$

\footnotetext{
${ }^{3}$ For interested readers, further information and discussions of the market characteristics and financial sector development of these countries can be found in Neaime (2005) and Naceur and Ghazouani (2007).
} 
Figure 1: GCC countries and oil dependency

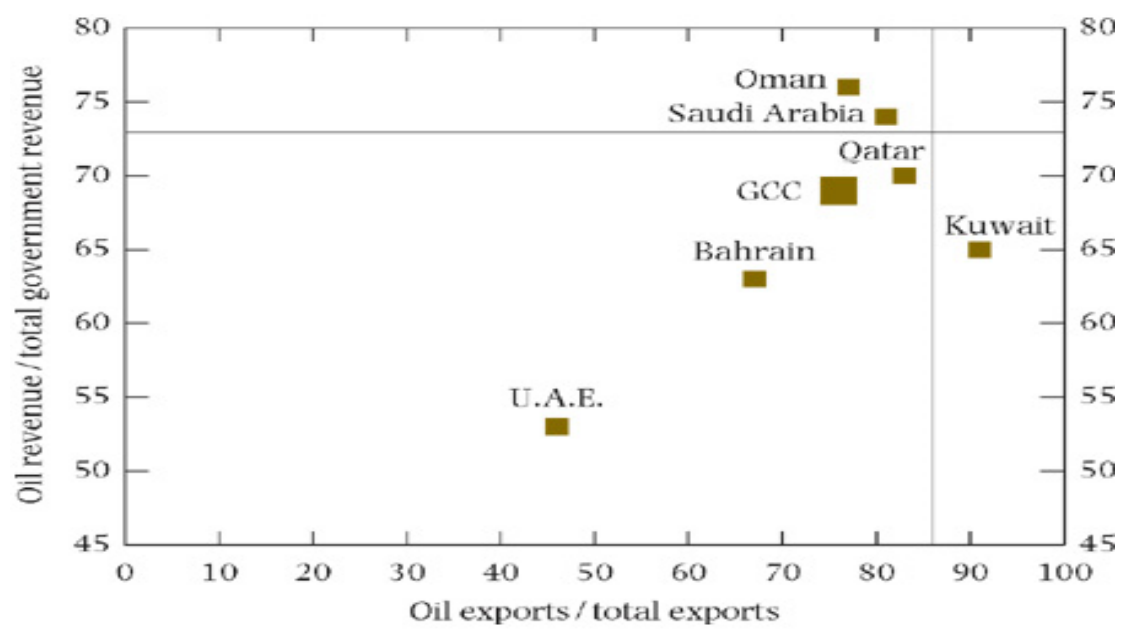

Source: Fasano and Iqbal (2003), International Monetary Fund.

Finally, GCC countries may have much in common, but they depend on oil to differing degrees and are making differing efforts to diversify and liberalize their economies. For example, the UAE and Bahrain are less dependent on oil than Saudi Arabia and Qatar (Figure 1). The comparison of GCC stock markets thus makes for an interesting subject. The paneldata econometric tools we use in this paper take into account these different features.

\section{Panel Granger causality test methodology}

The panel-data approach developed by Kónya (2006) is based on the following bivariate (here an oil price index, oil; and a stock market index, stock) finite-order vector autoregressive model:

$$
\left\{\begin{array}{l}
\text { oil }_{i t}=\alpha_{1, i}+\sum_{j=1}^{p_{1 i}} \beta_{1, i, j} \text { oil }_{i, t-j}+\sum_{j=1}^{p_{2 i}} \gamma_{1, i, j} \text { stock }_{i, t-j}+\varepsilon_{1, i, t} \quad t=1, \ldots, T \quad i=1, \ldots, N \quad(1 a) \\
\text { stock }_{i t}=\alpha_{2, i}+\sum_{j=1}^{p_{1 i}} \beta_{2, i, j} \text { oil }_{i, t-j}+\sum_{j=1}^{p_{2 i}} \gamma_{2, i, j} \text { stock }_{i, t-j}+\varepsilon_{2, j, t} \quad t=1, \ldots, T \quad i=1, \ldots, N
\end{array}\right.
$$


where the index $i(i=1, \ldots, N)$ is the country, the index $t(t=1, \ldots, T)$ the period, $j$ the lag, and $p_{1 i}, p_{2 i}$ and $p_{3 i}$, the longest lags in the system. The error terms, $\varepsilon_{1, i, t}$ and $\varepsilon_{2, i, t}$, are supposed to be white-noise and may be correlated with each other for a given country.

The seemingly unrelated regressions (SUR) procedure (since possible links may exist among individual regressions via contemporaneous correlation ${ }^{4}$ within equations (1a) and (1b) of system (1) is used to estimate system (1). Wald tests for Granger causality are then done with country-specific bootstrap critical values generated by simulations.

With respect to system (1), for instance, in country i there is one-way Granger-causality running from stock to oil if in the first equation not all $\gamma_{1, i}$ are zero but in the second all $\beta_{2, i}$ are zero; there is one-way Granger-causality from oil to stock if in the first equation all $\gamma_{1, i}$ are zero but in the second not all $\beta_{2, i}$ are zero; there is two-way Granger-causality between from oil to stock if neither all $\beta_{2, i}$ nor all $\gamma_{1, i}$ are zero; and there is no Granger-causality between oil to stock if all $\beta_{2, i}$ and $\gamma_{1, i}$ are zero. $^{5}$

This procedure has several advantages. Firstly, it does not assume that the panel is homogenous, so it is possible to test for Granger-causality on each individual panel member separately. However, since contemporaneous correlation is allowed across countries, it makes it possible to exploit the extra information provided by the panel data setting. Secondly, this approach does not require pretesting for unit roots and cointegration (since country-specific bootstrap critical values are generated), though it still requires the specification of the lag

\footnotetext{
${ }^{4}$ This assumption is very likely to be relevant for many macroeconomic time series for GCC countries for which strong economic links exist.

${ }^{5}$ As stressed by Kónya (2006), this definition implies causality for one period ahead.
} 
structure. This is an important feature since the unit-root and cointegration tests in general suffer from low power, and different tests often lead to contradictory outcomes. Thirdly, this panel Granger causality approach allows the researcher to detect for how many and for which members of the panel there exists one-way Granger-causality, two-way Granger-causality or no Granger-causality.

\section{Econometric investigation}

First, we present the datasets we use in our empirical investigation of the link between oil prices and stock returns in GCC countries. Then, we discuss the results we obtain at both weekly and monthly frequencies.

\subsection{Data}

Unlike previous studies, which use low-frequency data (yearly, quarterly or monthly), our study uses both weekly and monthly data for the reasons discussed in the introduction of the paper.

Weekly data are obtained from MSCI and covered the six GCC members. We think that weekly data may more adequately capture the interaction of oil and stock prices in the region than low-frequency data. We do not use daily data in order to avoid time difference problems with international markets. In fact, the equity markets are generally closed on Thursdays and Fridays in GCC countries, while the developed and international oil markets close for trading on Saturdays and Sundays. Furthermore, for the common open days, the GCC markets close just before US stocks and commodity markets open. Accordingly, we opt to use weekly data and choose Tuesday as the weekday for all variables because this day lies in the middle of the three common trading days for all markets. Moreover, the data used in all the analyses predate the end of 2005, so previous studies missed the spectacular evolutions that took place in the GCC and oil markets in the last three years. Therefore, our sample period goes from 7 June 2005 to 21 October 2008 for the six GCC members. 
As for our second dataset, we use monthly data obtained from Arab Monetary Fund (AMF) over the period January 1996 - December 2007. Note that stock exchanges in UAE and Qatar are newly established and did not participate in the AMF database when it began in 2002 . Thus, the AMF data we use include only four of the six GCC stock markets: Bahrain, Kuwait, Oman and Saudi Arabia. ${ }^{6}$

For oil, we use the weekly and monthly OPEC spot prices. These prices are weighted by estimated export volume and are obtained from the Energy Information Administration (EIA). OPEC prices are often used as benchmarks for crude oil, including oil produced by GCC countries. $^{7}$ All prices are in American dollars.

\subsection{Empirical results}

We report in Tables 2a, $2 \mathrm{~b}$ and 3a, 3b below the results for the Granger causality tests (associated respectively to our weekly and monthly datasets), using a bivariate model, from stock markets to oil prices, and from to oil prices to stock markets for GCC countries.

Table 2a - Granger causality tests from stock markets to oil prices for the Gulf Corporation Countries panel (weekly dataset from 7 June 2005 to 21 October 2008 on the 6 GCC countries), bivariate (OIL, STOCK) model

\begin{tabular}{lccccc}
\hline \hline Country & Estimated & Test Statistic & \multicolumn{3}{c}{ Bootstrap critical values } \\
\cline { 4 - 6 } & coefficient & & $1 \%$ & $5 \%$ & $10 \%$ \\
\hline Bahrain & 0.02811 & 2.08482 & 5.66717 & 4.03923 & 3.17804 \\
Kuwait & -0.01252 & -.620305 & 6.39197 & 5.00073 & 3.62678 \\
Oman & 0.01638 & 0.73068 & 6.4651 & 4.37293 & 3.67639 \\
Saudi Arabia & -0.09361 & $-3.79621^{* *}$ & 5.6690 & 3.08229 & 2.00697 \\
Qatar & 0.00759 & 0.44267 & 52.2202 & 3.70653 & 2.62674 \\
United Arab Emirates & 0.01327 & 1.09262 & 5.0565 & 3.02775 & 2.84203 \\
\hline \hline
\end{tabular}

Notes: a) $* * *, * *$ and * denote significance at the $1 \%, 5 \%$ and $10 \%$ levels.

b) $\mathrm{H}_{0}$ : STOCK does not cause OIL.

OIL - oil prices, and STOCK - stock market indices (taken in logarithms).

Tables 2a and 2b show the existence of one-way direct Granger causality from the Saudi stock markets to OPEC oil prices. In fact, the null hypothesis of absence of causality is strongly

\footnotetext{
${ }^{6}$ Data for 2008 are not available in AMF database. Furthermore, weekly data are not available.

${ }^{7}$ Very similar results are obtained with West Texas Intermediate and Brent spot prices. Oil prices are in US dollars per barrel. Note also that GCC currencies have been officially pegged to the U.S. dollar since 2003. However, Kuwait has recently moved back to pegging its currency to a basket currency.
} 
rejected based on both weekly and monthly data. For the other GCC countries, changes in national stock indices do not significantly cause changes in oil prices.

Table 2b - Granger causality tests from stock markets to oil prices for the Gulf Corporation Countries panel (monthly dataset from January 1996 to December 2007 on 4 GCC countries), bivariate (OIL, STOCK) model

\begin{tabular}{lccccc}
\hline \hline Country & Estimated & Test Statistic & \multicolumn{3}{c}{ Bootstrap critical values } \\
\cline { 4 - 6 } & coefficient & & $1 \%$ & $5 \%$ & $10 \%$ \\
\hline Bahrain & 0.000038 & 0.393636 & 9.68393 & 4.68711 & 3.03222 \\
Kuwait & 0.000603 & 0.205246 & 0.80760 & 0.48910 & 0.30363 \\
Oman & -0.00024 & 0.150259 & 0.69011 & 0.476602 & 024491 \\
Saudi Arabia & -0.000010 & $1.343260^{* * *}$ & 0.88615 & 0.577966 & 0.23960 \\
\hline \hline
\end{tabular}

Notes: a) ***, ** and * denotes significance at the $1 \%, 5 \%$ and $10 \%$ levels, respectively. b) $\mathrm{H}_{0}$ : STOCK does not cause OIL.

OIL - oil prices, and STOCK - stock market indices (taken in logarithms).

Our findings are not totally unexpected for at least two reasons. First, the Saudi market is the biggest stock market in the region: it makes up more than $40 \%$ of all GCC markets and onethird of all Arab markets. Second, Saudi Arabia plays a leading role in worldwide energy markets. Indeed, estimates show that Saudi Arabia has about 260 billion barrels of oil reserves, some $24 \%$ of the world's proven total. The production quotas of OPEC member countries are based on their proven reserves. The greater their reserves, the more they can produce. Hence, Saudi Arabia is the world's largest exporter of total petroleum liquids and is currently the world's second largest crude oil producer behind Russia. In 2007, International Monetary Fund statistics showed that oil export revenues accounted for around $90 \%$ of total Saudi export earnings and state revenues and more than $40 \%$ of the country's GDP. Our empirical results suggest that changes in the Saudi stock markets, which should reflect changes in the Saudi economy, significantly cause changes in OPEC oil prices. 
Table 3a - Granger causality tests from oil prices stock markets for the Gulf Corporation Countries panel (weekly dataset from 7 June 2005 to 21 October 2008 on the 6 GCC countries),

bivariate (OIL, STOCK) model

\begin{tabular}{lccccc}
\hline \hline Country & Estimated & Test Statistic & \multicolumn{2}{c}{ Bootstrap critical values } \\
\cline { 3 - 5 } & coefficient & & $1 \%$ & $5 \%$ & $10 \%$ \\
\hline Bahrain & 0.00191 & $0.14211^{*}$ & 0.29211 & 0.14789 & 0.00911 \\
Kuwait & 0.00231 & $0.13652^{* *}$ & 0.30546 & 0.12611 & 0.07768 \\
Oman & 0.00155 & $0.09968^{* *}$ & 0.16304 & 0.08177 & 0.05540 \\
Saudi Arabia & -0.0400 & $1.14244^{* * *}$ & 0.46554 & 0.24260 & 0.17622 \\
Qatar & 0.00003 & $0.10445^{*}$ & 0.26374 & 0.11511 & 0.07641 \\
United Arab Emirates & 0.00022 & $0.34326^{* *}$ & 0.38124 & 0.22056 & 0.16416 \\
\hline \hline
\end{tabular}

Notes: a) $* * *, * *$ and $*$ denote significance at the $1 \%, 5 \%$ and $10 \%$ levels.

b) $\mathrm{H}_{0}$ : OIL does not cause STOCK.

Tables 3a and 3b show that oil price changes significantly affect stock market returns in all GCC countries. These results are robust and highly significant at both weekly and monthly data frequencies. These findings are not surprising given the role played by oil revenues in all GCC economies (cf. Figure 1). In fact, oil price increases raise national and corporate revenues; stock market returns are affected.

Table 3b - Granger causality tests from oil prices stock markets for the Gulf Corporation Countries panel (monthly dataset from January 1996 to December 2007 on 4 GCC countries), bivariate (OIL, STOCK) model

\begin{tabular}{lccccc}
\hline \hline Country & Estimated & Test Statistic & \multicolumn{3}{c}{ Bootstrap critical values } \\
\cline { 4 - 6 } & coefficient & & $1 \%$ & $5 \%$ & $10 \%$ \\
\hline Bahrain & 1.32582 & $8.362054^{* * *}$ & 7.31205 & 4.06357 & 2.56081 \\
Kuwait & 0.20590 & $3.425624^{* *}$ & 5.06262 & 3.05210 & 2.93863 \\
Oman & 0.08286 & $0.8525599^{* *}$ & 1.4490 & 0.84143 & 0.15531 \\
Saudi Arabia & 0.35612 & $5.189276^{* * *}$ & 3.84234 & 2.72987 & 1.19159 \\
\hline \hline
\end{tabular}

Notes: a) ***, ** and * denotes significance at the $1 \%, 5 \%$ and $10 \%$ levels, respectively. b) $\mathrm{H}_{0}$ : OIL does not cause STOCK.

In short, there is strong bi-directional Granger causality between oil price changes and Saudi stock market returns. The Saudi market has a close link to the price of oil and can predict it. In other words, oil prices affect stock prices in Saudi Arabia and political and economic shocks that influence Saudi Arabia can have an impact on oil prices. For the other GCC countries, significant Granger causalities are obtained from oil price changes to stock market returns, 
results that suggest that oil price changes affect stock markets in these countries but that changes in these markets do not significantly affect oil prices. In conclusion, traders in the GCC stock markets should look at the changes in oil prices, whereas investors in oil markets should look at changes in the Saudi stock market.

\section{Conclusion and policy implications}

In the literature, relatively little work has focused on the sensitivity of the stock markets in oil-importing countries to oil price changes. The case of oil-exporting countries is not well investigated. This paper studied the relationship between oil prices and stock markets in GCC countries. GCC members are major net oil-exporters and important OPEC members and their economies are excessively dependent on oil prices. Thus, their actions as decision makers in OPEC may take into account their impact on GCC stock markets and economic activities.

Using the panel-data approach of Kónya (2006), which is based on SUR systems and Wald tests with country-specific bootstrap critical values, and two different (weekly and monthly) datasets covering respectively the periods from 7 June 2005 to 21October 2008, and from January 1996 to December 2007, we show strong statistical evidence that the causal relationship is consistently bi-directional for Saudi Arabia. In the other GCC countries, stock market price changes do not Granger cause oil price changes, whereas oil price shocks Granger cause stock price changes. Therefore, investors and policy makers in the GCC stock markets should keep an eye on changes in oil prices because these changes significantly affect stock returns. On the other hand, investors in world oil markets should look at changes in the Saudi stock market because theses changes significantly affect oil prices. 


\section{$\underline{\text { References }}$}

- Balaz, P. and Londarev, A. (2006), "Oil and its position in the process of globalization of the world economy”. Politicka Ekonomie, 54 (4), 508-528.

- Bashar, Z. (2006), "Wild oil prices, but brave stock markets! The case of Gulf Cooperation Council (GCC) stock markets”, Middle East Economic Association Conference, Dubai.

- Basher, S. A. and Sadorsky, P. (2006), "Oil Price Risk and Emerging Stock Markets”, Global Finance Journal, 17, 224-251.

- Breitung, J. and Pesaran, M. (2005). "Unit Roots and Cointegration in Panels", in Matyas, L., Sevestre, P. (eds.), The Econometrics of Panel Data, Klüver Academic Press.

- Cologni, A. and Manera M. (2008), "Oil prices, inflation and interest rates in a structural cointegrated VAR model for the G-7 countries.” Energy Economics, 30, 856-88.

- Cunado, J., Perez de Garcia, F. (2005), "Oil prices, economic activity and inflation: evidence for some Asian countries.” The Quarterly Review of Economics and Finance 45 (1), 65-83.

- Fasano, U., and Iqbal, Z. (2003), "GCC Countries: from oil dependence to diversification”, International Monetary Fund, Washington D.C.

- Gronwald, M. (2008). "Large oil shocks and the US economy: Infrequent incidents with large effects,” Energy Journal, 29, 151-71.

- Hammoudeh, S. and Aleisa, E. (2004), 'Dynamic relationship among GCC stock markets and NYMEX oil futures', Contemporary Economic Policy, Vol. 22, pp.250-269.

- Hammoudeh, S. and Choi, K. (2006), "Behavior of GCC Stock Markets and Impacts of US Oil and Financial Markets,” Research in International Business and Finance, Vol. 20 no. 1, pp. 22-44.

- Huang, R. D., Masulis, R. W., and Stoll H. R. (1996), "Energy shocks and financial markets,” Journal of Futures Markets, 16, 1-27.

- Jones, C.M. and Kaul, G. (1996), "Oil and the Stock Markets”, Journal of Finance, vol. 51, n² 2, pp. 463-491.

- Kilian, L. (2008), "Exogenous Oil Supply Shocks: How Big Are They and How Much Do They Matter for the US Economy?”, Review of Economics and Statistics, 90, 216-40.

- Kónya, L. (2006), "Exports and growth: Granger causality analysis on OECD countries with a panel data approach”, Economic Modelling, 23, 978-982. 
- Lardic S. and Mignon V. (2006), “The impact of oil prices on GDP in European countries: An empirical investigation based on asymmetric cointegration”, Energy Policy, vol. 34(18), pp. 3910-3915.

- Lardic S. and Mignon V. (2008), “Oil prices and economic activity: An asymmetric cointegration approach”, Energy Economics, vol. 30(3), pp. 847-855.

- Naceur, S. B. and Ghazouani, S. (2007), "Stock markets, banks, and economic growth: empirical evidence from MENA region”, Research in International Business and Finance, Vol. 21, pp. 297-315.

- Neaime, S. (2005), "Financial market integration and macroeconomic volatility in the MENA region: an empirical investigation”, Review of Middle East Economics and Finance, Vol. 3, pp. 231-253.

- Papapetrou, E. (2001), “Oil Price Shocks, Stock Market, Economic Activity and Employment in Greece,” Energy Economics, 23, 511-32.

- Sadorsky, P. (1999), Oil Price Shocks and Stock Market Activity, Energy Economics, vol. 2, pp. 449-469.

- Shiller, R.J. and Perron, P. (1985), Testing the random walk hypothesis: Power versus frequency of observation, Economic Letters 18, 381-386. 


\section{DAVIDSON INSTITUTE WORKING PAPER SERIES - Most Recent Papers}

The entire Working Paper Series may be downloaded free of charge at: www.wdi.umich.edu

CURRENT AS OF 6/18/09

\begin{tabular}{|c|c|c|}
\hline Publication & Authors & Date \\
\hline $\begin{array}{l}\text { No. 960: Oil Prices \& Stock Markets: What Drives What in the Gulf } \\
\text { Corporation Council Countries? }\end{array}$ & $\begin{array}{l}\text { Christophe Rault and Mohamed } \\
\text { El Hedi Arouri }\end{array}$ & June 2009 \\
\hline $\begin{array}{l}\text { No. 959: Trade Specialisation And Economic Convergence: } \\
\text { Evidence From Two Eastern European Countries }\end{array}$ & $\begin{array}{l}\text { Christophe Rault, Guglielmo } \\
\text { Caporale, Robert Sova \& } \\
\text { Anamaria Sova }\end{array}$ & June 2009 \\
\hline $\begin{array}{l}\text { No. 958: Inflation differentials in the Euro area and their determinants } \\
\text { - an empirical view }\end{array}$ & $\begin{array}{l}\text { Juan Ignacio Aldasoro \& Václav } \\
\text { Žd'árek }\end{array}$ & April 2009 \\
\hline No. 957: Infrastructure and growth: Empirical evidence & $\begin{array}{c}\text { Balazs Egert, Tomasz } \\
\text { Kozluk and Douglas Sutherland }\end{array}$ & April 2009 \\
\hline $\begin{array}{l}\text { No. 956: Infrastructure investment in network industries: The role of } \\
\text { incentive regulation and regulatory independence }\end{array}$ & Balazs Egert & April 2009 \\
\hline $\begin{array}{l}\text { No. 955: The impact of monetary and commodity fundamentals, macro } \\
\text { news and central bank communication on the exchange rate: } \\
\text { Evidence from South Africa }\end{array}$ & Balazs Egert & April 2009 \\
\hline $\begin{array}{l}\text { No. 954: "Family" ownership, tunneling and earnings management: } \\
\text { A review of the literature }\end{array}$ & $\begin{array}{l}\text { Sumon Bhaumik and Andros } \\
\text { Gregoriou }\end{array}$ & $\begin{array}{l}\text { March } \\
2009\end{array}$ \\
\hline $\begin{array}{l}\text { No. 953: Impact of Foreign Direct Investments on Industrial Productivity: } \\
\text { A Subnational Study of India }\end{array}$ & Krishna C. Vadlamannati & $\begin{array}{l}\text { March } \\
2009\end{array}$ \\
\hline $\begin{array}{l}\text { No. 952: Determinants of Exchange Rate Practices in the MENA } \\
\text { Countries: Some Further Empirical Results }\end{array}$ & Sfia, M. Daly and Mouley Sami & Jan 2009 \\
\hline No. 951: An Analytic Approach To Selecting A Nonprofit & $\begin{array}{l}\text { Andrés Ramírez and } \\
\text { Hakan Saraoglu }\end{array}$ & Jan 2009 \\
\hline $\begin{array}{l}\text { No. 950: Anthropometry of Love } \\
\text { Height and Gender Asymmetries in Interethnic Marriages }\end{array}$ & Michèle Belot and Jan Fidrmuc & Jan 2009 \\
\hline No. 949: Is THE COST OF LIVING IN RUSSIA REALLY THAT LOW? & Konstantin Gluschenko & Dec 2008 \\
\hline $\begin{array}{l}\text { No. 948: Banking Market Liberalization and Bank Performance: the Role } \\
\text { of Entry Modes }\end{array}$ & Ngoc-Anh Vo Thi & Jan 2009 \\
\hline $\begin{array}{l}\text { No. 947: The Monetary Union: The Decade Ahead. } \\
\text { The Case of Non-Member States }\end{array}$ & Daniel Daianu and Laurian Lungu & Jan 2009 \\
\hline No. 946: Currency Substitution: A Case Of Kazakhstan (2000:1-2007:12) & $\begin{array}{l}\text { Mesut Yilmaz, Yessengali } \\
\text { Oskenbayev \& Kanat Abdulla }\end{array}$ & Jan 2009 \\
\hline $\begin{array}{l}\text { No. 945: Determinants Of Pollution Abatement And Control Expenditure: } \\
\text { Evidence From Romania }\end{array}$ & $\begin{array}{l}\text { Guglielmo Caporale, Christophe } \\
\text { Rault, Robert Sova \& Anamaria } \\
\text { Sova }\end{array}$ & Jan 2009 \\
\hline $\begin{array}{l}\text { No. 944: Bootstrap panel Granger-causality between government } \\
\text { spending and revenue in the EU }\end{array}$ & $\begin{array}{l}\text { Antonio Afonso and Christophe } \\
\text { Rault }\end{array}$ & Jan 2009 \\
\hline No. 943: Regional Determinants of FDI Distribution in Poland & $\begin{array}{l}\text { Agnieszka Chidlow and Stephen } \\
\text { Young }\end{array}$ & Nov 2008 \\
\hline No. 942: Structural Reform and Firm Exports & $\begin{array}{l}\text { Alvaro Cuervo-Cazurra \& Luis } \\
\text { Alfonso Dau }\end{array}$ & Sept 2008 \\
\hline $\begin{array}{l}\text { No. 941: Exploring The Relationship Between Military Spending \& } \\
\text { Human Rights Performance In South Asia }\end{array}$ & $\begin{array}{l}\text { Krishna Chaitanya, Vadlamannati } \\
\text { and K K Shakya Lahiru Pathmalal }\end{array}$ & Oct 2008 \\
\hline $\begin{array}{l}\text { No. 940: Structural Reform And Firm Profitability In Developing } \\
\text { Countries }\end{array}$ & $\begin{array}{l}\text { Alvaro Cuervo-Cazurra \& Luis } \\
\text { Alfonso Dau }\end{array}$ & July 2008 \\
\hline $\begin{array}{l}\text { No. 939: Does Timing Of Elections Instigate Riots? } \\
\text { A Subnational Study Of } 16 \text { Indian States, } 1958-2004\end{array}$ & Krishna Chaitanya Vadlamannati & Oct 2008 \\
\hline $\begin{array}{l}\text { No. 938: Price Setting And Market Structure: An Empirical Analysis Of } \\
\text { Micro Data }\end{array}$ & Fabrizio Coricelli \& Roman Horvath & Sept 2008 \\
\hline $\begin{array}{l}\text { No. 937: Inflation Differentials in EU New Member States: An Empirical } \\
\text { Evidence }\end{array}$ & Roman Horvath \& Kamila Koprnicka & Oct 2008 \\
\hline
\end{tabular}

